\title{
Field efficacy and persistence of synthetic pesticidal dusts on stored maize grain under contrasting agro-climatic conditions
}

\author{
Shaw Mlambo ${ }^{1}$, Brighton M. Mvumi ${ }^{*}$, Tanya Stathers ${ }^{2}$, Macdonald Mubayiwa $^{1}$, Tinashe Nyabako ${ }^{1}$ \\ ${ }^{1}$ Soil Science \& Agricultural Engineering, Faculty of Agriculture, University of Zimbabwe, Box MP 167 Harare, \\ Zimbabwe \\ ${ }^{2}$ Natural Resources Institute, University of Greenwich, Central Avenue, Chatham maritime, Kent ME4 4TB, UK \\ *Corresponding author. Phone: +263 772419 983; +263712 442440 \\ E-mail address: mvumibm@hotmail.com; mvumibm@agric.uz.ac.zw
}

Abstract

Grain storage trials were conducted in two districts of Zimbabwe with contrasting agro-climatic conditions (mean annual temperature of $18-30{ }^{\circ} \mathrm{C}$ and $28-42{ }^{\circ} \mathrm{C}$; total rainfall of $750-1000$ $\mathrm{mm}$ per annum and < $450 \mathrm{~mm}$ per annum; respectively) to determine the comparative efficacy of commercially-available grain storage synthetic pesticides under contrasting climatic conditions. The five grain protectants, namely Shumba super dust ${ }^{\circledR}$ (fenitrothion $1 \%+$ deltamethrin 0.13

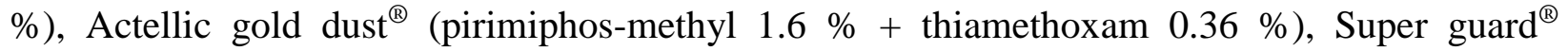
(pirimiphos-methyl $1.6 \%+$ permethrin $0.4 \%$ ), Chikwapuro ${ }^{\circledR}$ (pirimiphos-methyl $2.5 \%+$ deltamethrin $0.1 \%$ ) and Ngwena yedura ${ }^{\circledR}$ (pirimiphos-methyl $2.5 \%+$ deltamethrin $0.2 \%$ ) were evaluated at label rates on stored shelled maize. The trials were conducted for a 40 week-long storage season in 2014/15 and again in 2015/16. Samples were analysed for insect grain damage, total insects per kilogram, grain weight loss, insect feeding chaff and grain moisture content. Temperature and relative humidity within stores were recorded using data loggers. The results highlighted the generally poor efficacy of the synthetic pesticides under both cooler and hotter climatic test conditions. The pesticides failed to prevent insect grain damage or suppress insect pest numbers. Only Actellic gold dust ${ }^{\circledR}$, introduced in the 2015/16 storage season was effective under both the agro- climatic conditions. The current study suggests that only Actellic gold dust ${ }^{\circledR}$ can be recommended for smallholder farm grain protection under both cooler and hotter climatic conditions. The findings confirm the frequent claims of smallholder farmers in east and southern Africa regarding poor storage pesticide performance, and emphasize the need to develop alternative effective storage insect pest control options.

Key words: Grain storage, synthetic pesticide efficacy, insect feeding chaff, grain damage, Prostephanus truncatus 


\section{INTRODUCTION}

37 The increased production and use of synthetic pesticides worldwide since the 1960s has helped reduce pest infestations, boost food production and extend food shelf-life (Ortiz-hernández et al., 2013). Most pesticides are targeted at reducing pest species which attack crops during the field growth stages, thus helping to increase agricultural production. Far fewer pesticides are available for protecting grain from insect infestation after harvest. Given the climatic projections of global increases in temperatures, the efficacy of pesticides may be reduced (Arthur et al., 1992; Stathers et al., 2013), while pest infestation may rise, affecting both the crop production and storage stages.

In the current study, the efficacy of the five commercially available grain storage pesticides in Zimbabwe was investigated on stored maize. These grain storage synthetic pesticides are widely used in Zimbabwe, with at least $75 \%$ of farmers relying on them to protect their stored grain from insect pests (Mvumi and Stathers, 2003; Nyabako et al., in preparation). Grain protectants containing a wide variety of active ingredients, including carbamates, pyrethroids, organophosphates and neonicotinoids have been formulated, and most of them contain more than ingredient (Arthur, 1996). These binary formulations are employed to improve efficacy and reduce development of insect tolerance which can occur more easily to products with a single active ingredient (Daglish and Nayak, 2012; Rumbos et al., 2013). However, little information is available on the effect of temperature and relative humidity on the efficacy of binary pesticides in grain storage (Rumbos et al., 2013). Theses is particularly important under farm conditions where a combination of extreme temperatures and new pests such as the larger grain borer (LGB), Prostephanus truncatus Horn. (Coleoptera: Bostrichidae) are experienced.

The documented effects of temperature on pesticide activity differ by pesticide class. The efficacy of organophosphate and neonicotinoid-based insecticides increases with increasing temperature from 20 to $30{ }^{\circ} \mathrm{C}$ (Arthur et al., 2004; Vassilakos and Athanassiou, 2013) while that of pyrethroid pesticides decrease as temperatures increase (Subramanyam and Cutkomp, 1987;

62 Arthur, 1999). Some studies suggest that although high temperatures generally decrease the 63 efficacy of pesticides; organophosphates are more effective at temperatures above $20{ }^{\circ} \mathrm{C}$, than $\leq$ $6420{ }^{\circ} \mathrm{C}$ (Arthur et al., 2004). This is understood to be due to increased pest movement, breathing 65 and uptake rate of the pesticide at higher temperatures (Arthur et al., 2004). Other researchers 
noted that whilst mortality increased at high temperatures in the first few days of pesticide (organophosphates) application, general efficacy and pesticide persistence decreased over a long storage period (Hamacher et al., 2002). Similarly, studies by Afridi et al. (2000) concluded that degradation of organophosphate (chlorpyriphos-methyl and pirimiphos-methyl) and pyrethroid (permethrin) admixed pesticides is faster at temperatures of $35^{\circ} \mathrm{C}$ to $40{ }^{\circ} \mathrm{C}$ than at 25 to $30{ }^{\circ} \mathrm{C}$, and faster still on grain with a higher moisture content.

Furthermore, higher insect mortality was recorded at $75 \%$ r.h. than at $55 \%$ r.h., not as a result of "insecticide activity per se but due to the increased metabolic stress of the target insect species" (Vassilakos and Athanassiou, 2013). However, in most studies, temperature is considered more important than relative humidity in influencing pest activity resulting in increased pesticide contact or uptake at elevated temperatures (Rumbos et al., 2013). In terms of degradation, the residues of organophosphate pesticides degrade more rapidly than those of pyrethroids. For example, organophosphate residues on stored grain were below detection point after 52 weeks of grain storage, while the pyrethroid permethrin was more stable (Afridi et al., 2000). In terms of insect survival, Arthur et al. (2004) reported that the rusty red flour beetle, Tribolium castaneum (Herbst) (Coleoptera; Tenebrionidae), a secondary pest of stored cereals, has a better chance of survival after pesticide application since it attacks stored maize at a later stage when the pesticide has likely degraded, compared to primary pests such as the maize weevil, Sitophilus zeamais Motschulsky (Coleoptera; Curculionidae) which infests grain as it matures and persists throughout the postharvest stages.

Three classes of insecticides namely; organophosphates, pyrethroids and neonicotinoids; are commonly used in Zimbabwe and other countries in sub-Saharan Africa in grain protection as dust formulations. The insecticidal dusts are admixed with dried grain to protect it against storage insect pest damage. The organophosphates include pirimiphos-methyl and fenitrothion (Hazard class II). This class of pesticides has a quick knock-down effect and a fast degradation pathway and hence do not leave long-term residues after application (Tadeo, 2008). The pyrethroids include deltamethrin and permethrin. They are contact poisons which affect the nervous system and present low mammalian toxicity risks (Hazard class II); hence they are often viewed as the safest of all pesticides in terms of use (Kamrin, 2000). The neonicotinoids group of insecticides include thiamethoxam which interferes with the nicotinic acetylcholine receptors 
(Arthur et al., 2004), thus affecting the insect nervous system (Maienfisch et al., 2001). This unique mode of action makes them desirable for controlling insect pests which have developed some resistance to organophosphate, pyrethroid and carbamate insecticides (Maienfisch et al., 1999). The insecticide thiamethoxam, is widely used for seed treatment of most field crops but its documented use as a stored grain protectant is very low (Arthur et al., 2004).

An efficacy and persistence study of five synthetic insecticidal dusts admixed with maize grain was conducted in two agro-climatic regions of Zimbabwe with contrasting environmental conditions; one cool and sub-humid and the other hot and dry. The objective of the study was to determine the comparative efficacy and persistence of the grain protectants in contrasting climatic conditions, to deepen understanding of how the protectants perform as temperature and r.h. alter due to changing climatic conditions and provide guidance on validity of current recommendations.

\section{MATERIALS AND METHODS}

\subsection{Site description}

Field trials were conducted in Hwedza ( $\left.18^{\circ} 37^{\prime} \mathrm{S} ; 31^{\circ} 34^{\prime} \mathrm{E}\right)$ and Mbire $\left(20^{\circ} 43^{\prime} \mathrm{S} ; 30^{\circ} 34^{\prime} \mathrm{E}\right)$ districts in Zimbabwe. Hwedza district, located in agro-ecological region II b receives an annual rainfall of $750-1000 \mathrm{~mm}$ and mean annual temperatures of $18-30{ }^{\circ} \mathrm{C}$ (FAO, 2006). Mbire district, is located in agro-ecological region $\mathrm{V}$ characterised by low rainfall below $450 \mathrm{~mm}$ per annum and extreme temperatures ranging from $28-42{ }^{\circ} \mathrm{C}(\mathrm{FAO}, 2006)$. A rise of about $2.6{ }^{\circ} \mathrm{C}$ and $2{ }^{\circ} \mathrm{C}$ in minimum and maximum daily temperatures respectively, has been recorded in the last 30 years in Zimbabwe (Brown, 2012). This warming has resulted in increasing aridity as well as marked shifts in the onset of rains, increased proportions of low rainfall years and increased frequency of mid-season dry spells (Nyabako and Manzungu, 2012; Rurinda et al., 2013). The changes have resulted in a proposed shifting of Zimbabwe's agro-ecological zoning (Nyabako and Manzungu, 2012; Brown, 2012; Mugandani et al., 2012).

\subsection{Treatments}

Most of the grain protectant pesticides used in Zimbabwe are organophosphate- and pyrethroidbased including Shumba super dust ${ }^{\circledR}$, Chikwapuro ${ }^{\circledR}$, Ngwena yedura ${ }^{\circledR}$ and Super guard ${ }^{\circledR}$; even 
127 though they differ in terms of their specific active ingredients and respective percentages (Table

128 1). Only Actellic gold ${ }^{\circledR}$ dust contains a neonicotinoid active ingredient in combination with an organophosphate. The pesticides were purchased from Farm \& City, a registered agro-dealer in Harare, Zimbabwe. Untreated grain in polypropylene bags was used as a control for the experiment.

\section{Insert Table 1 about here}

\subsection{Trial setting and management}

In Hwedza district, a 1:2 mixture of two hybrid maize varieties; Sirda 113 (Seed Company of Zimbabwe- Seed-co) and PHB 30G19 (Pioneer Seed Company) were used in the trials during the 2014/15 season whilst in the 2015/16 season a 1:3 mixture of PHG 30G19 and Pioneer 2859 (Pioneer Seed Company) was used. Mixtures were used due to a local shortage of sufficient bulk grain of a single variety as a result of poor growing seasons. In Mbire district, a single variety of PHB 30G19 was used in both the grain storage seasons. In both districts, grain was purchased in the same locality where the trials were conducted.

The same grain treatment process was used in both districts. The trial grain was thoroughly mixed at one place. Each treatment was allocated $75 \mathrm{~kg}$ of grain and treated with a respective pesticide. Manufacturer's recommended application rates were used for all pesticides (Table 1). After pesticide treatment, the $75 \mathrm{~kg}$ lot of each treatment was sub-divided to make three $25 \mathrm{~kg}$ replicates contained in polypropylene bags.

Brick wall structures with cement floors, ceiling boards and asbestos roofs housed the treatments in both districts. Data loggers (EL-USB-2, USA) were used to record temperature and rh in the trial rooms. In the 2014/15 season, the loggers were installed eight weeks after trial setting due to their late delivery. Polypropylene bags of $50 \mathrm{~kg}$ capacity were used to contain the treated grain and these were placed on a raised platform (about $10 \mathrm{~cm}$ above the floor) of mud bricks in a completely randomised design (CRD). Immediately after trial setting, baseline samples were collected. Thereafter, sampling was conducted at eight-week intervals over a period of forty weeks. Sampling was done using $40 \mathrm{~cm}$ bag probes (Hodges, 2013) inserted horizontally at 
multiple points across the circumference and different levels of the bag. Grain samples were analysed to determine grain moisture content, presence of live and dead insects, grain damage, chaff weight and grain weight loss. The trials relied on natural insect infestation; no insects were artificially introduced into the treatments.

\subsection{Sample analysis and calculations}

For each sample, the weight was recorded before sieving off the insects. Two and five millimetre aperture standard test sieves were nested to separate the chaff and insects respectively from the grain. Live and dead insect counts were converted to the number of live or dead insects per kilogram of sample. The live and dead insects per kilogram were summed up to give total insects per kilogram of sample weight. Grain moisture content was measured using a pre-calibrated GrainPro moisture meter (model GMK- 303CF, GrainPro Inc, Philippines). Thereafter, samples were kept in a freezer at $\leq-18{ }^{\circ} \mathrm{C}$ to stop further insect damage whilst grain damage assessment was underway. For damage assessment, each maize sample was sub-divided into eight subsamples using a grain sample divider. Three sub-samples, equivalent to three-eighths of the total sample were analysed for grain damage. Damaged and undamaged grain was separated manually and each category counted using a seed counter (Numigral seed counter, CHOPIN, Villeneuve LA Garenne, France). Damage was then converted to percentage as $[N d /(N d+U n d)] \times 100 \%$ where $N d$ represents the number of damaged grains and Und represents the number of undamaged grains (Boxall, 1986). Grain weight loss was calculated using the count and weigh assessment method (Equation 1):

$$
\text { Weight loss } \%=\frac{N d W u-W d N u}{(N d+N u) \times W u} \times 100 \text { (Boxall, 1986) Equation } 1
$$

where $N d=$ number of damaged grains in a sample, $N u=$ number of undamaged grains in a sample, $W u=$ weight of undamaged grains in a sample and $W d=$ weight of damaged grains in a sample.

\subsection{Data analysis}

Square root transformations were done on the data including insect grain damage, weight loss and insect feeding chaff to stabilise data variance and conform to normality (Kirchner, 2001). Thereafter, the data were subjected to a two-way analysis of variance in Genstat 14 (VSN 
International, 2011) to test for significant differences between treatments, sites and treatment-site interactions. In case of significant differences, Fisher's protected LSD at $5 \%$ probability was used to separate means. Temperature data, recorded using data loggers for the two sites, were analysed using a paired sample t-test.

\section{RESULTS}

\subsection{Grain damage}

\subsubsection{Season $1(2014 / 15)$}

In Hwedza, grain insect damage increased swiftly in the untreated control from slightly above $10 \%$ at 16 weeks to above $40 \%$ of grains at week 24 . However, in the pesticide treatments, grain damage remained much lower throughout the trial (Fig. 1). It was only after 32 and 40 weeks storage, respectively, that grain damage in two of the pesticide treatments, Ngwena yedura $^{\circledR}$ and Super guard ${ }^{\circledR}$, rose above $10 \%$ during the 2014/15 storage season. In Mbire district, grain damage levels were generally higher in the respective treatments, than those recorded in Hwedza except for the untreated control where damage levels began to rise at week 16 whereas in the pesticide treatments, this occurred as from week 32 (Fig. 1). Differences in grain damage among treatments were significant $\left(\mathrm{F}_{4,20}=5.60 ; \mathrm{P}=0.003\right)$ within sites at week 40. However, there were no significant differences $\left(F_{1,20}=2.35 ; \mathrm{P}=0.141\right)$ for inter-site comparison. Treatment-site interactions were significant $\left(\mathrm{F}_{4}, 20=4.62 ; \mathrm{P}=0.008\right)$ showing that treatments performed differently across the two sites. For combined data across sites, Shumba super dust ${ }^{\circledR}$ had the least damage followed by Super guard ${ }^{\circledR}$, Chikwapuro $^{\circledR}$, Ngwena yedura $^{\circledR}$ and untreated control.

\section{Insert Figure 1 about here}

\subsubsection{Season $2(2015 / 16)$}

In the 2015/16 storage season in Hwedza, grain damage remained below $10 \%$ in all treatments only up to week 16 . In contrast to the previous season, grain damage remained below $10 \%$

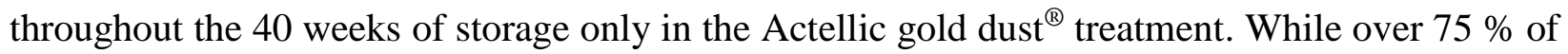
grains were damaged in the untreated control, Shumba super dust ${ }^{\circledR}$, Chikwapuro ${ }^{\circledR}, \mathrm{Ngwena}$ yedura $^{\circledR}$ and Super guard ${ }^{\circledR}$ by week 40 (Fig. 2). It is striking that all the organophosphate- and 
220

221

222

223

224

225

226

227

228

229

230

231

232

233

234

235

236

237

238

239

240

241

242

243

244

245

246

247

248

249

250

pyrethroid-based pesticide treatments (Shumba super dust ${ }^{\circledR}$, Ngwena yedura $^{\circledR}$, Super guard ${ }^{\circledR}$ and Chikwapuro ${ }^{\circledR}$ ) experienced very high grain damage similar to levels found in the untreated control grain. However, the Actellic gold dust ${ }^{\circledR}$ treatment, which contains a neonicotinoid in combination with an organophosphate active ingredient was effective throughout the storage period.

In Mbire district, grain damage levels were much lower than in Hwedza. In the Actellic gold dust $^{\circledR}$, Chikwapuro ${ }^{\circledR}$ and Shumba super dust ${ }^{\circledR}$ treatments mean percentage insect damaged grain remained below $10 \%$ throughout the 40 weeks of storage (Fig. 2). Statistically, treatments were significantly different $\left(\mathrm{F}_{5,24}=33.20 ; \mathrm{P}<0.001\right)$ when data was combined across the sites at 40 weeks. Site comparisons were also significant $\left(\mathrm{F}_{1,24}=311.67\right.$; $\left.\mathrm{P}<0.001\right)$; together with treatment-site interactions $\left(\mathrm{F}_{5,24}=16.56 ; \mathrm{P}<0.001\right)$. Actellic gold dust ${ }^{\circledR}$ produced a stand-alone performance followed by Shumba super dust ${ }^{\circledR}$, Chikwapuro ${ }^{\circledR}$ and Ngwena yedura ${ }^{\circledR}$ whilst Super guard $^{\circledR}$ and the untreated control had the highest damage for combined sites data.

\section{Insert Figure 2 about here}

\subsection{Grain weight loss}

\subsubsection{Season $1(2014 / 15)$}

Weight losses remained below $4 \%$ in all the pesticide treatments in Hwedza during the 2014/15 season. Only $11 \%$ weight loss occurred in the untreated control by 40 weeks storage. In Mbire district, grain weight losses were generally low, remaining below $8 \%$ throughout the trial, with the highest figures of $7.8 \%$ and $6.8 \%$ occurring in the Chikwapuro ${ }^{\circledR}$ and Ngwena yedura ${ }^{\circledR}$ treatments respectively (Fig. 3). Differences in grain weight losses for combined treatments were significant $\left(\mathrm{F}_{4,20}=3.13 ; \mathrm{P}=0.037\right)$ at 40 weeks of storage. The site differences were not significant but treatment-site interactions had significant differences $\left(\mathrm{F}_{4}, 20=3.82 ; \mathrm{P}=0.018\right)$. Across sites, Shumba super dust ${ }^{\circledR}$ had the least weight losses, followed categorically by Super guard $^{\circledR}$, Chikwapuro $^{\circledR}$, Ngwena yedura $^{\circledR}$, with the untreated grain experiencing the highest weight losses.

\section{Insert Figure 3 about here}




\subsubsection{Season $2(2015 / 16)$}

In Hwedza district, weight loss started to increase from week 16 onwards in the untreated control, Shumba super dust ${ }^{\circledR}, \mathrm{Chikwapuro}^{\circledR}, \mathrm{Ngwena}$ yedura ${ }^{\circledR}$ and Super guard ${ }^{\circledR}$, all these treatments suffered very high weight losses of $20 \%$ and above by 32 and 40 weeks storage. It was only in the Actellic gold dust ${ }^{\circledR}$ treatment that weight loss remained below $1 \%$ throughout the 40 weeks of storage (Fig. 4). In Mbire, weight losses were much lower ( $\leq 10 \%)$ compared to those in Hwedza. Significant differences at 40 weeks were recorded between treatments $\left(\mathrm{F}_{5,24}=\right.$ 10.57; $\mathrm{P}<0.001)$, sites $\left(\mathrm{F}_{1,24}=144.56 ; \mathrm{P}<0.001\right)$ and treatment-site interactions $\left(\mathrm{F}_{5,24}=9.98 ; \mathrm{F}\right.$ $<$.001). The lowest weight losses were incurred in Actellic gold dust ${ }^{\circledR}$ followed surprisingly by the untreated control. Shumba super dust ${ }^{\circledR}$, Chikwapuro ${ }^{\circledR}$ and Ngwena yedura ${ }^{\circledR}$ recorded similarly high losses and Super guard ${ }^{\circledR}$ had the highest across site weight losses.

\section{Insert Figure 4 about here}

\subsection{Adult insect species diversity}

\subsubsection{Season $1(2014 / 15)$}

In Hwedza, the maize weevil $S$. zeamais was the dominant insect species recorded during the 2014/15 storage season. The beetle P.truncatus was recorded at week 32 and 40 in most treatments. The highest number of insects was recorded in the untreated controls, with over 300 adult insects per kilogram at week 24 . The insect population remained below 50 insects per $\mathrm{kg}$ in the Shumba super dust ${ }^{\circledR}$ (in both Mbire and Hwedza) as well as Chikwapuro ${ }^{\circledR}$ and Ngwena yedura $^{\circledR}$ treatments during the entire 40 weeks of storage, and Super guard ${ }^{\circledR}$ only exceeded 50 insects per kilogram at 32 and 40 weeks (Fig. 5).

In the same season lower populations of insects were recorded in Mbire than in Hwedza, but the spectrum of insect species was wider. Prostephanus truncatus was more prevalent in the pesticide-treated grain especially Chikwapuro ${ }^{\circledR}, \operatorname{Ngwena}$ yedura ${ }^{\circledR}$ and Super guard ${ }^{\circledR}$, whereas S. zeamais was more pronounced in untreated and Shumba super dust treatments. Tribolium castaneum, being a secondary pest of maize, was more prevalent towards the end of the storage season although in the untreated control it was recorded earlier at 16 weeks. The grain moth 
Sitotroga cerealella (Olivier) (Lepidoptera; Gelechiidae) and wasps of the hymenoptera order were also recorded in most treatments (Fig. 5).

Treatments had significant differences $\left(\mathrm{F}_{4,20}=7.26 ; \mathrm{P}<0.001\right)$ for across site comparisons at 40 weeks. Treatment-site interactions were also significant $\left(\mathrm{F}_{4,20}=7.59 ; \mathrm{P}<0.001\right)$. However, site differences were not significant in influencing insect populations. The insects were highest in untreated control, followed by Super guard ${ }^{\circledR}$ and Ngwena yedura ${ }^{\circledR}$, Chikwapuro ${ }^{\circledR}$ and Shumba super dust ${ }^{\circledR}$ in that order.

\section{Insert Figure 5 about here}

\subsubsection{Season $2(2015 / 16)$}

In Hwedza, P.truncatus was the main insect pest recorded in treated grain whilst high populations of S. cerealella were also present in the untreated grain. High insect populations (600 - 800 insects per kg) were recorded in the Ngwena yedura $^{\circledR}$, untreated control, Shumba super dust ${ }^{\circledR}$, Chikwapuro ${ }^{\circledR}$ and Super guard ${ }^{\circledR}$ (Fig. 6). Actellic gold dust ${ }^{\circledR}$ out-performed the other treatments, with less than 50 adult insects per kg by 40 weeks storage. In contrast to the 2014/15 season, S. zeamais was recorded at very low levels in most treatments except the untreated control at week 40. In Mbire district, S. cerealella and S. zeamais were dominant from trial setting in August 2015 to week 24 in most treatments. However, in the untreated control, T. castaneum also became dominant from week 24 to week 40, whereas in Ngwena yedura ${ }^{\circledR}$ and Super guard ${ }^{\circledR}$, P. truncatus became dominant at week 32 and 40. The total insect numbers per kilogram recorded in Mbire of up to 220 insects per kilogram were much less than those recorded in Hwedza (above 600 insects per kilogram) for the same treatments (Fig. 6).

Across sites, both treatments $\left(\mathrm{F}_{5,24}=9.20 ; \mathrm{P}<0.001\right)$ and sites $\left(\mathrm{F}_{1,24}=177.91 ; \mathrm{P}<0.001\right)$ were significantly different. Treatment-site interactions were also significant $\left(\mathrm{F}_{5,24}=7.01 ; \mathrm{P}<0.001\right)$ hence performance of treatments across sites differed. Actellic gold dust ${ }^{\circledR}$ had the least number of total insects followed by the untreated control for pooled data. Chikwapuro ${ }^{\circledR}$, Shumba super dust $^{\circledR}$ and Super guard ${ }^{\circledR}$ were in the same range and Ngwena yedura ${ }^{\circledR}$ had the highest number of total insects. 
313

314

\subsection{Insect feeding dust}

3.4.1 Season $1(2014 / 15)$

Very little insect feeding dust or chaff $(<2 \%$ by weight) was generated in any of the pesticide treatments in Hwedza during the 2014/15 storage season, and it only reached $4 \%$ in the untreated control by week 40. In Mbire, Shumba super dust ${ }^{\circledR}$ and the untreated control recorded below $1 \%$ chaff dust, whilst Super guard $^{\circledR}$, Chikwapuro ${ }^{\circledR}$ and Ngwena yedura ${ }^{\circledR}$ recorded between 2 and $4 \%$ chaff. Only treatment-site interactions were significant $\left(\mathrm{F}_{4,20}=3.53 ; \mathrm{P}=\right.$ $0.025)$ at 40 weeks of storage.

\subsubsection{Season $2(2015 / 16)$}

In contrast to the 2014/15 storage season, during the 2015/16 season, large quantities of feeding/boring dust were generated in Hwedza from week 24 onwards, rising to between 10 and $25 \%$ by week 40. Only Actellic gold dust ${ }^{\circledR}$ remained with little chaff. Greater quantities of chaff were generated in the pesticide treatments Chikwapuro ${ }^{\circledR}$, Super guard ${ }^{\circledR}$, Ngwena yedura $^{\circledR}$ and Shumba super dust ${ }^{\circledR}$ than the untreated control at week 40. Again, almost no dust/chaff was recorded in the Actellic gold dust ${ }^{\circledR}$. In the Mbire district, all treatments recorded very low chaff content below $5 \%$ (Fig. 7). Treatments were significantly different $\left(\mathrm{F}_{5,24}=11.13 ; \mathrm{P}<0.001\right)$ across sites. The two sites also had significant differences $\left(\mathrm{F}_{1,24}=151.03 ; \mathrm{P}<0.001\right)$ and treatment-site interactions were also significant $\left(\mathrm{F}_{5,24}=9.23 ; \mathrm{P}<0.001\right)$.

\section{Insert Figure 7 about here}

\subsection{Grain moisture content, store temperature and relative humidity}

\subsubsection{Season $1(2014 / 15)$}

In Hwedza district, moisture content of the trial grain ranged from 9 to $12 \%$ during the 40 week trial. Moisture content increased from trial setting in November 2014 to February 2015 before stabilizing at around $11 \%$ from March to June (Fig. 8). Temperatures for Hwedza were 
342 consistently below $25{ }^{\circ} \mathrm{C}$ except in January and March 2015. On the other hand, r.h. ranged 343 between 50 and $70 \%$ for most of the season and only dropped below $50 \%$ in June. In Mbire grain moisture content dropped from $10 \%$ to about $9 \%$, between November 2014 and January 2015 before rising to a peak of $11 \%$ in March 2015 (Fig. 8). During this period temperatures were beyond $30{ }^{\circ} \mathrm{C}$ for most of the time except in January 2015 when heavy rains and flooding occurred in Mbire (13 weeks into the trial). Relative humidity was highly variable in Mbire, rising from as low as $30 \%$ during the hot dry summer in November to above $70 \%$ in the hot wet summer in January 2015. Between February and June of 2015, r.h. decreased gently from about $65 \%$ to $40 \%$. There were no significant differences in grain moisture content between treatments for across site comparisons. However, the sites were significantly different $\left(\mathrm{F}_{1,20}=\right.$ 83.66; $\mathrm{P}<0.001)$. Treatment-site interactions were also insignificant, statistically. There were significant differences in mean temperatures for Hwedza and Mbire districts (Paired sample ttest: $\mathrm{T}=-5.88 ; \mathrm{N}=8, \mathrm{P}<0.001)$.

\section{Insert Figure 8 about here}

\section{Insert Figure 9 about here}

\subsubsection{Season $2(2015 / 16)$}

In the 2015/16 season, grain moisture content in Hwedza district decreased from $12 \%$ in September 2015 to about $9.6 \%$ in December before rising gently and remaining at around $11 \%$ until the end of the season. During the season steady temperatures of 25 to $27{ }^{\circ} \mathrm{C}$ were recorded, and only dropping below $25^{\circ} \mathrm{C}$ in April and May 2016 (Fig. 9). Relative humidity decreased from 40 to $35 \%$ between September and October 2015 before rising steadily to above $50 \%$ from January 2016 onwards. In Mbire district, grain moisture content decreased steeply from $12 \%$ to about $7 \%$ between September and December 2015 (Fig. 8) in response to high temperatures (Fig. 9) which were consistently high above $30{ }^{\circ} \mathrm{C}$ during that period. Grain moisture content then increased between December 2015 and January 2016, then remained constant at just below $10 \%$ until the season's end in May 2016. The hot dry spells of Mbire resulted in r.h. falling below $30 \%$ in September and October 2015 before a rapid rise to slightly above $50 \%$ between November and December. Beginning 2016, r.h. remained steady above $50 \%$ until April, when it 
373 dropped to about $42 \%$ in May. No significant differences in grain moisture content between 374 treatments were recorded for across site comparisons. Treatment-site interactions were also not 375 significant. However, sites were significantly different $\left(\mathrm{F}_{1,24}=71.96 ; \mathrm{P}<0.001\right)$ at 40 weeks. 376 Significant differences were also confirmed for the mean temperatures (Paired sample $\mathrm{t}$-test: $\mathrm{T}=$ $377-5.22 ; \mathrm{N}=9 ; \mathrm{P}<0.001)$ of the two sites.

378

379

380

381

382

383

384

385

386

387

388

389

390

391

392

393

394

395

396

397

398

399

400

401

402

\section{DISCUSSION}

The study found that the performance of grain storage pesticides differed across the sites and was influenced by the contrasting environmental conditions. This resulted in significant treatmentsite interactions. Grain damage and weight losses in the pesticide treated maize grain were higher in Mbire than Hwedza district in the 2014/15 season, although this was not the case for the untreated control. However, in the 2015/16 season, damage and weight losses in all treatments were higher in Hwedza than Mbire district. In the 2014/15 season, Shumba super dust ${ }^{\circledR}$ effectively suppressed damage in treated grain in both districts, and Chikwapuro ${ }^{\circledR}$ was equally as effective but only in Hwedza district. In the 2015/16 storage season, in Hwedza district, grain damage levels were very high in all treatments except Actellic gold dust ${ }^{\circledR}$ after 40 weeks storage. In contrast, in the hotter more arid Mbire district, insect grain damage was suppressed in all pesticide treatments for 32 weeks storage after which high damage levels were recorded in Super $\operatorname{guard}^{\circledR}$ and Ngwena yedura ${ }^{\circledR}$ in 2015/16.

Several other recent storage studies from African countries (Mutambuki and Ngatia, 2012, Abass et al., 2014; Midega et al., 2016), also reported grain damage levels as high as those experienced in Hwedza in 2015/16, where over $70 \%$ grain was damaged and $40 \%$ weight losses recorded. In many African countries, P. truncatus and S. zeamais are ranked as the most destructive stored maize insect pests (Midega et al., 2016), and the former is estimated to cause double the losses caused by $S$. zeamais (Hodges, 2002). Some farmers perceive P. truncatus to account for about $56 \%$ and S. zeamais up to $36 \%$ of the maize losses (Abass et al., 2014). In the current trial, $P$. truncatus and $S$. zeamais were the main cause of high grain damage and weight losses.

The damage levels and pest populations varied widely between the two seasons in Mbire district, which may be linked to climatic aspects. As in the 2014/15 storage season, flooding occurred in 
Mbire between January and February 2015 during which time temperatures dropped to below $30{ }^{\circ} \mathrm{C}$ and grain moisture content simultaneously rose to a high of $11 \%$. In relation to grain damage and pest infestations, there were no sudden fluctuations in response to flooding or environmental conditions as the effects took longer to manifest. Higher damage levels and insect populations did not manifest immediately in response to the flooding and changed environmental conditions, but occurred later on from April to June 2015 (after 32 and 40 weeks storage). Generally, the higher the grain moisture content, the more susceptible the grain is to insects (Rashid et al., 2013).

Another factor which may have caused wide variability in grain damage and pest populations between seasons in the Mbire trials may be the excessively high temperatures experienced during the El-Niño heat wave (WFP, 2016) which affected the 2015/16 season. During this season there was a very slow build-up of insect populations in Mbire trials enabling all the pesticide treatments to perform fairly well for 32 weeks of grain storage. However, a sudden dramatic increase in damage occurred by 40 weeks storage in the untreated control, Super guard ${ }^{\circledR}$ and Ngwena yedura $^{\circledR}$ treatments after temperatures dropped below $30^{\circ} \mathrm{C}$. It is possible that pest build-up was suppressed in the earlier weeks due to the excessively high temperatures experienced during the heat wave. As optimum conditions for life cycle development of most storage insect pests fall in the ranges of $27-32{ }^{\circ} \mathrm{C}$ at $72 \%$ r.h., excessive temperatures above $35{ }^{\circ} \mathrm{C}$ may slow establishment (Mason and McDonough, 2011). It is likely that the heatwave caused pesticide breakdown, leaving insect populations to increase with little restriction when temperatures dropped to optimal levels.

Additionally the different grain moisture content levels experienced in the two districts $(9-12 \%$ mc in Hwedza, and as low as $8.5 \%$ in Mbire district), which were linked to the high temperatures, may also have influenced insect pest development. When temperatures are high and grain moisture content is so low, it becomes difficult for insects to perforate grain (Rashid et al., 2013) or to breed (Beckett et al., 2007), and hence grain damage is typically lower. There were significant differences between sites for the across site comparisons of grain moisture content confirming that site conditions influenced treatment grain moisture content. Furthermore, the generally higher r.h. (> $50 \%$ ) of Hwedza was more favourable for insect pest development compared to the drier conditions (<30\% r.h.) of Mbire district. Typically, optimum conditions 
for S. zeamais development are $25{ }^{\circ} \mathrm{C}$ at $70 \%$ r.h., $35^{\circ} \mathrm{C}$ at $75 \%$ r.h. for T. castaneum and $32{ }^{\circ} \mathrm{C}$ at $80 \%$ r.h. for P. truncatus (Haines, 1991; Fields, 1992). Prostephanus truncatus has, however, higher tolerance to drier conditions (Haines, 1991).

Overall, no general pattern across the two districts for the two storage seasons in terms of pesticide efficacy as measured by grain damage, weight loss, pest prevalence and abundance was found. As noted earlier, in the 2014/15 season, damage, weight loss and $P$. truncatus prevalence were higher in Mbire than Hwedza district. However, in the 2015/16 season, the reverse occurred with higher grain damage, weight loss and P. truncatus populations recorded in Hwedza than in Mbire district. Similarly, the pesticides were fairly effective in Hwedza in 2014/15, but less so in Mbire. However, the 2015/16 season's trial found all the pesticides except Actellic gold dust ${ }^{\circledR}$ perfomed poorly. The variabilities in terms of damage, weight levels and $P$. truncatus prevalence across the two seasons may be attributed to the characteristically sporadic occurrence of P. truncatus (Boxall, 2003; Hodges et al., 2003; Muantinte et al., 2014). According to Krall (1984), damage and losses caused by P. truncatus are difficult to measure due to their often isolated and unpredictable occurrence. The pest's presence is known to be sporadic between treatments, farm stores and storage seasons (Boxall, 2003; Hodges et al., 2003). This was the case across treatments, sites and seasons in both Hwedza and Mbire districts during these trials. Therefore, any pesticide used needs to be able to perform whether $P$. truncatus is present or not that year, because the risk of food shortages is so high if the pest does attack.

In terms of general pesticide efficacy, the grain damage and total insect numbers graphs clearly demonstrate the failure of most of the pesticides in suppressing insect pest development in both study districts. With the exception of Actellic gold dust ${ }^{\circledR}$ which performed very well in both districts, and Shumba super dust ${ }^{\circledR}$ in the 2014/15 season, all the other pesticides succumbed to insect pressure. These studies found that the organophosphate and pyrethroid pesticide combinations failed to control insect pests and only Actellic gold dust ${ }^{\circledR}$ which is composed of an organophosphate (pirimiphos-methyl $1.6 \%$ ) and a neonicotinoid (thiamethoxam $0.36 \%$ ) performed well across the two contrasting environmental conditions. In this case, the neonicotinoid (thiamethoxam $0.36 \%$ ) active ingredient appears to be the differential active ingredient between the poor and high efficacy pesticides. Failure of organophosphate and 
pyrethroid pesticides can be attributed to either poor pesticide persistence or pesticide tolerance and/ resistance, among other factors.

Earlier laboratory studies of pirimiphos-methyl (organophosphate) in stored-maize under hothumid conditions $\left(30{ }^{\circ} \mathrm{C},>50 \%\right.$ relative humidity) showed that it was effective for a short duration of four months after which efficacy was greatly reduced (Richter et al., 1997). Pirimiphos-methyl and fenitrothion (organophosphates) have also been categorised as less persistent pesticides at $30{ }^{\circ} \mathrm{C}$ temperatures, whilst deltamethrin and permethrin (pyrethroids) showed higher persistence over a nine months storage period (Morton et al., 2001). Therefore considering the 40 weeks storage duration $(\approx 10$ months $)$ of this current trial and the high temperatures experienced in both districts, it might have been too long a period for effective storage, especially considering the pesticides' low persistence. Although deltamethrin and permethrin have in previous studies shown higher persistence (Morton et al., 2001), in the current study the effectiveness of products in which they were included barely lasted 24 weeks.

Besides the poor persistence, poor efficacy of synthetic pesticides may also be a result of pesticide dilution by high chaff dust. The dust generated due to extensive tunneling by P. truncatus has the potential to dilute the pesticidal dust, making it ineffective (Mlambo et al., 2017). This is also one of the reasons why delayed pesticide application results in pesticide failure (Mutambuki and Ngatia, 2012). At the same time, it was also noted in some cases that untreated grain suffered less damage and weight loss than pesticide- treated grain which can be due to the high sensitivity of natural enemies to synthetic pesticides (Stathers et al., 2008). Studies done by Stathers et al., (2008) indicate that natural enemies (parasitic wasps) numbers were higher in untreated grain compared to pesticide treatments, showing how natural enemies can be killed in treated grain but survive in untreated grain and help to regulate insect populations and hence lower damage.

Pesticide resistance world-wide is being fueled by the over-reliance on synthetic pesticides, mainly organophosphates and pyrethroids for grain storage (Pereira et al., 2009). "Low levels of resistance" in the case of S. zeamais have been reported in South America (Pereira et al., 2009). Strains of R. dominica with "normal" and "intermediate" tolerance as well as high resistance factors have also been screened (Lorini and Galley, 1999; Chen and Chen, 2013). Resistance of S. zeamais and T. castaneum to pirimiphos-methyl and fenitrothion has also been reported 
492 (Lorini and Galley, 1999). It is concerning that even laboratory cultures of the S. zeamais and

493 T. castaneum species showed resistance to these pesticides without any obvious selection 494 pressure (Lorini and Galley, 1999). Furthermore, Collins (1998) postulated that elimination of 495 weaker insects due to rapid field selection will make it even more difficult to control insect pests.

496 The dominant insect species in this trial P. truncatus and S. zeamais, may therefore have 497 developed some form of resistance to some of these pesticides and this calls for further studies to 498 investigate pest resistance to organophosphate and pyrethroid pesticides in Zimbabwe and the 499 SSA subcontinent as a whole.

500 Due to the novelty of the neonicotinoid, thiamethoxam as a grain protectant (Khan et al., 2016), 501 development of resistance may be minimal compared to the more commonly applied 502 organophosphates and pyrethroids. To manage the development of pesticide resistance, the 503 poorly performing pesticides should be withdrawn from the market to avoid continuous selection 504 for resistant insect species.

505

506

507

508

509

510

511

512

513

514

515

516

517

518

519

520

521

\section{CONCLUSION}

Our study demonstrates the generally poor efficacy of the organophosphate and pyrethroid grain protectant combinations currently commercially available in Zimbabwe, under both cooler and hotter climatic conditions. This study confirms frequent reports by farmers that the synthetic insecticidal dusts on the market are not effective. Only Actellic gold dust ${ }^{\circledR}$, which contains a neonicotinoid (thiamethoxam $0.36 \%$ ) active ingredient suppressed insect pest build-up, minimising insect grain damage and grain weight losses in both districts. These findings highlight the need for further research to investigate why the efficacy of these organophosphate and pyrethroid grain protectants is poor. The very high temperatures and minimal grain moisture conditions experienced in Mbire district during the 2015/16 season appear to have suppressed insect development in the stored grain compared to the more favourable insect-developmental temperature ranges of Hwedza district. The study showed that the general efficacy of synthetic pesticide on stored maize grain varies across different climatic conditions and only Actellic gold dust $^{\circledR}$ was efficacious under both the hotter and cooler climatic areas, suggesting it can be widely recommended. Nevertheless, as documented by Blacquière et al. (2012), the neonicotinoid components of the pesticide also negatively affect pollinator bees so the search for effective and safer (to both humans and the environment) alternatives to synthetic pesticides needs to continue. 
522 The simultaneous effects of multiple insect stressors such as pesticides, and extreme 523 temperatures, especially high temperature, and low relative humidity (hence low grain moisture content) on both pests and natural enemies needs further investigation.

525

526

527

528

529

530

531

532

533

534

535

536

537

538

539

540

541

542

543

544

545

546

547

548

549

550

551

552

553

554 555

\section{ACKNOWLEDGEMENTS}

The authors are grateful to the European Union (EU) for funding the project "Supporting smallholder farmers in southern Africa to better manage climate-related risks to crop production and post-harvest handling" through the leadership of the Food and Agriculture Organisation (FAO) (Project code OSRO/RAF/22O/EC). National extension services in Hwedza and Mbire districts are also appreciated for their active engagement and contributions. Gratitude is also extended to Dr Susan Richardson Kageler (Department of Crop Science, University of Zimbabwe) for assistance in statistical analysis. Mention of a trademark or proprietary product does not constitute a guarantee or warranty of the product by the University of Zimbabwe or Natural Resources Institute and does not imply its approval to the exclusion of other products that may also be suitable.

\section{Highlights}

- High grain damage and weight loss occurred in stored maize treated with most organophosphate-pyrethroid combinations

- The organophosphate-neonicotinoid-based pesticide restricted grain damage and losses below $5 \%$ for 40 -weeks storage

- Poor pesticide efficacy occurred in both cool and hot climatic locations

- Prostephanus truncatus prevalence increased the magnitude of weight losses recorded

- Extremely high ambient temperatures suppress insect pest development and grain damage

\section{REFERENCES}

Afridi, I.A.K., Zahida Parveenb, S. Zafar Masud., 2000. Stability of organophosphate and pyrethroid pesticides on wheat in storage. Journal of Stored Products Research 37, 199204.

Arthur, F.H. Throne, J.E. Simonaitis, R.A., 1992. Degradation and biological efficacy of chlorpyrifos-methyl on wheat stored at five temperatures and three moisture contents. Journal of Economic Entomology 85, 1994-2002

Arthur, F.H., 1996. Grain protectants: current status and prospects for the future. Journal of Stored Products Research 32, 293-302. 
Arthur, F.H., 1999. Effect of temperature on residual toxicity of cyfluthrin wettable powder. Journal of Economic Entomology 92, 695-699.

Arthur, F.H., Yue, B., Wilde, G.E., 2004. Susceptibility of stored-product beetles on wheat and maize treated with thiamethoxam: Effects of concentration, exposure interval, and temperature. Journal of Stored Products Research 40, 527-546. doi:10.1016/j.jspr.2003.08.001

Abass, A.B., Ndunguru, G., Mamiro, P., Alenkhe, B., Mlingi, N., Bekunda, M., 2014. Postharvest food losses in a maize-based farming system of semi-arid savannah area of Tanzania. Journal of Stored Products Research 57, 49 - 57.

Beckett, S.J., Fields, P.G., Subramanyam, Bh., 2007. Disinfection of stored products and associated structures using heat, p182-237 In Tang J., Mitcham. E., Wang. S., Lurie, S. (Ed.). Heat Treat ments for Postharvest Pest Control: Theory Practice. CABI Publishing.

Blacquière, T., Smagghe, G., Van Gestel, C.A.M., Mommaerts, V., 2012. Neonicotinoids in bees: A review on concentrations, side-effects and risk assessment. Ecotoxicology 21, 973-992. doi:10.1007/s10646-012-0863-x

Boxall, R.A., 1986. A critical review of the methodology for assessing farm-level grain losses after harvest. Report of the Tropical Development and Research Institute, G191, viii + $139 \mathrm{pp}$.

Boxall, R.A.A., 2003. Damage and loss caused by the Larger Grain Borer Prostephanus truncatus. Integrated Pest Management Reviews 7, 105-121. doi:10.1023/A:1026397115946

Brown, D., 2012. Climate change impacts, vulnerability and adaptation in Zimbabwe, GeoJournal. doi:10.1023/B:GEJO.0000003613.15101.d9

Chen, C., Chen, M., 2013. Susceptibility of field populations of the lesser grain borer, Rhyzopertha dominica ( F .), to deltamethrin and spinosad on paddy rice in Taiwan. Journal of Stored Products Research 55, 124-127. doi:10.1016/j.jspr.2013.10.001

Collins, P.J., 1998. Inheritance of resistance to pyrethroid insecticides in Tribolium castaneum ( Herbst ). Journal of Stored Products Research 34, 395-401.

Daglish, G.J., Nayak, M.K., 2012. Potential of the neonicotinoid imidacloprid and the oxadiazine indoxacarb for controlling five coleopteran pests of stored grain. Insect Science 19, 96 101.

FAO, 2006. Fertiliser use by crop in Zimbabwe. Rome. Available at http:// http://www.fao.org/docrep/009/a0395e/a0395e00.htm. (Accessed 12 June 2015).

Fields, P.G., 1992. The control of stored-product insects and mites with extreme temperatures. Journal of Stored Products Research 28, 89-118. doi:10.1016/0022-474X(92)90018-L

Haines, C.P., 1991. Insects and arachnids of tropical stored products : their biology and identification (a training manual). Natural Resources Institute, pp: 246. Available at http://agris.fao.org/agris-search/search.do?recordID=GB19960110794 
605

606

607

608

609

610

611

612

613

614

615

616

617

618

619

620

621

622

623

624

625

626

627

628

629

630

631

632

633

634

635

636

Hamacher, L.S., Faroni, L.R.A., Guedes, R.N.C., Queiróz, M.E.L.R., 2002. Persistence and activity towards Sitophilus zeamais (Coleoptera: Curculionidae) of pirimiphos-methyl sprayed at different temperatures on maize. Journal of Stored Products Research 38, 167175.

Hodges, R., 2002. Detection and monitoring of larger grain borer, Prostephanus truncatus (Horn) (Coleoptera: Bostrichidae). Integrated Pest Management Reviews 7, 223-243.

Hodges, R.J., Addo, S., Birkinshaw, L., 2003. Can observation of climatic variables be used to predict the flight dispersal rates of Prostephanus truncatus? Agricultural and Forestry Entomology 5, 123-135. doi:10.1046/j.1461-9563.2003.00170.x

Hodges, R., 2013. How to assess postharvest cereal losses and their impact on grain supply: rapid weight loss estimation and the calculation of cumulative cereal losses with the support of APHLIS. APHLIS 2013, 1-104.

Kamrin, M.A., 2000. Pesticide profiles toxicity, Environmental impact and fate. Boca Raton: CRC Press.

Khan, T., Shahid, A.A., Azhar, H., Khan, A., 2016. Could biorational insecticides be used in the management of aflatoxigenic Aspergillus parasiticus and its insect vectors in stored wheat? PeerJ 4:e1665; doi:10.7717/peerj.1665

Kirchner, J.W., 2001. 'Data analysis toolkit \# 3: Tools for transforming data'. Available at http://seismo.berkeley.edu/ kirchner/eps_120/EPSToolkits.htm (Accessed 8 August 2015).

Krall, S., 1984. A new threat to farm-level maize storage in West Africa: Prostephanus truncatus (Horn) (Coleoptera: Bostrichidae). Tropical Stored Products Information 50, 26-31.

Lorini, I., Galley, D.J., 1999. Deltamethrin resistance in Rhyzopertha dominica ( F .) (Coleoptera : Bostrichidae), a pest of stored grain in Brazil. Journal of Stored Products Research 35, 37-45.

Maienfisch, P.L., Gsell, L., Rindlisbacher, A., 1999. Synthesis and insecticidal activity of CGA 293343 - a novel broad spectrum insecticide. Pesticide Science 55, 351-354.

Maienfisch, P.L., Huerlimann, H., Rindlisbacher, A., Gsell, L., Dettwiler, H., Haettenschwiler, J., Sieger, E., Walti, M., 2001. The discovery of thiamethoxam: a second-generation neonicotinoid. Pest Management Science 57, 165-176.

Mason, L., McDonough, M., 2011. Biology, behaviour, and ecology of stored grain and legume insects. Stored Products Protection pp 1-14. Kansas State University, Kansas State.

Midega, C.A.O., Murage, A.W., Pittchar, J.O., Khan, Z.R., 2016. Managing storage pests of maize: Farmers' knowledge, perceptions and practices in western Kenya. Crop Protection 90, 142-149. doi:10.1016/j.cropro.2016.08.033 
Mlambo, S., Mvumi, B.M., Stathers, T., Mubayiwa, M., Nyabako, T., 2017. Field efficacy of hermetic and other maize grain storage options under smallholder farmer management. Crop Protection 98, 198-210. doi:10.1016/j.cropro.2017.04.001

Morton, R., Brayan, J.G., Desmarchelier, J.M., Dilli, S., Haddad, P.R., Sharp, G.J., 2001. Statistical analysis of decay of organophosphorus and pyrethroid insecticides and carbaryl on paddy rice, maize, sunflowers and field peas. Journal of Stored Products Research 37, 277-285.

Muantinte, B.I., Van den Berg, J., Santos, L.A., 2014. Prostephanus truncatus in Africa: A review of biological trends and perspectives on future pest management strategies. African Crop Science Journal 22, 237-256.

Mugandani, R., Wuta, M., Makarau, A., Chipindu, B., 2012. Re-Classification of agro-ecological regions of Zimbabwe in conformity with climate variability and change. African Crop Science Journal, 20, Issue Supplements 2, 361 - 369

Mutambuki, K., Ngatia, C., 2012. Assessment of grain damage and weight loss on farm stored maize in highlands areas of Bungoma District, Kenya. Journal of Agricultural Science and Technology B 2, 349-361.

Mvumi, B., Stathers, T., 2003. Challenges of grain protection in sub-Saharan Africa: the case of diatomaceous earths., in: Food Africa Internet-Based Forum. pp. 1-6. Available at http://www.dfid.gov.uk/R4D/pdf/outputs/r8179challengesofgrainprotectionproceedings.p df (Accessed 15 June 2015)

Nyabako, T., Manzungu, E., 2012. An assessment of the adaptability to climate change of commercially available maize varieties in Zimbabwe. Environment and Natural Resources Research 2, 32- 46.DOI:10.5539/enrr.v2n1p32

Ortiz-hernández, M.L., Sánchez-salinas, E., Dantán-gonzález, E., Castrejón-godínez, M.L., 2013. Pesticide Biodegradation : Mechanisms, Genetics and Strategies to Enhance the Process. Biodegrad. Life Sciences 251-287. doi:10.5772/52777

Pereira, C.J., Pereira, E.J.G., Cordeiro, E.M.G., Lucia, T.M.C. Della, 2009. Organophosphate resistance in the maize weevil Sitophilus zeamais : Magnitude and behavior. Crop Protection 28, 168-173. doi:10.1016/j.cropro.2008.10.001

Rashid, S., Kurt, R., Carl, B., 2013. Effects of deterioration parameters on storage of maize: A Review. Journal of Natural Science Research 3, 2224-3186. doi:10.13031/aim.20131593351

Richter, B.J., Biliwa, A., 1997. Losses and pest infestation in different maize storage systems with particular emphasis on Prostephanus truncatus ( Horn ) ( Col ., Bostrichidae ) in Togo. Anzeiger für Schädlingskunde-Pflanzenschutz- Umweltschutz 70 (6): 112-116. 
708

709

710

711
Rumbos, C.I., Anna Cristina Dutton, Christos G. Athanassiou., 2013. Comparison of two pirimiphos-methyl formulations against major stored-product insect species. Journal of Stored Products Research 55, 106- 116.

Rurinda, J., Mapfumo, P., Wijk, M.T. Van, Mtambanengwe, F., Rufino, M.C., 2013. Field Crops Research Managing soil fertility to adapt to rainfall variability in smallholder cropping systems in Zimbabwe. Field Crops Research 154, 211-225. doi:10.1016/j.fcr.2013.08.012

Stathers, T.E., Riwa, W., Mvumi, B.M., Mosha, R., Kitandu, L., Mngara, K., Kaoneka, B., Morris, M., 2008. Do diatomaceous earths have potential as grain protectants for smallholder farmers in sub-Saharan Africa? The case of Tanzania. Crop Protection 27, 44-70. doi:10.1016/j.cropro.2007.04.020

Stathers, T., Lamboll, R., Mvumi, B.M., 2013. Postharvest agriculture in changing climate: Its importance to African smallholder farmers. Food Security 5, 361-392.

Subramanyam, Bh., Cutkomp, L.K., 1987. Influence of post treatment temperature on toxicity of pyrethroids to five species of stored-product insects. Journal of Economic Entomology 80, 9-13.

Tadeo, J.L., 2008. Analysis of pesticides in food and environmental samples. CRC Press, Taylor and Francis Group, London.

Vassilakos, T.N., Christos, G. Athanassiou., 2013. Effect of temperature and relative humidity on the efficacy of spinetoram for the control of three stored product beetle species. Journal of Stored Products Research 55 (2013) 73 - 77.

VSN International, 2011. GenStat for Windows 14th Edition. VSN International, Hemel Hempstead, UK. Web page: GenStat.co.uk.

WFP, 2016. WFP Regional El Niño Highlights : Situational analysis :pp. 5-8. Available at: http://reliefweb.int/sites/reliefweb.int/files/resources/WFP Southern Africa Regional El Nino Situation Report 2, 23 March 2016.pdf. 
717 Table 1: Treatments used in the experiment

\begin{tabular}{|c|c|c|c|c|c|c|c|c|c|}
\hline \multirow[b]{2}{*}{$\begin{array}{l}\text { Trade } \\
\text { name }\end{array}$} & \multirow[b]{2}{*}{ Active ingredients } & \multirow[b]{2}{*}{$\begin{array}{c}\text { Application } \\
\text { rate }(\mathrm{g} / 25 \mathrm{~kg} \\
\text { grain)* }\end{array}$} & \multicolumn{3}{|c|}{$\begin{array}{c}\text { Pesticide groups } \\
\text { combined in product }\end{array}$} & \multicolumn{2}{|c|}{$\begin{array}{r}\text { Hwedza } \\
\text { district }\end{array}$} & \multicolumn{2}{|c|}{$\begin{array}{l}\text { Mbire } \\
\text { district }\end{array}$} \\
\hline & & & 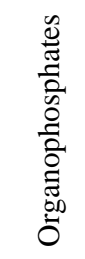 & 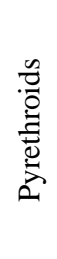 & $\begin{array}{l}0 \\
0 \\
.0 \\
0 \\
.0 \\
0 \\
0 \\
0\end{array}$ & 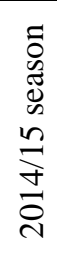 & 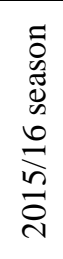 & 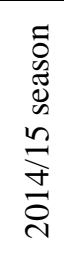 & 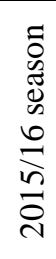 \\
\hline $\begin{array}{l}\text { Shumba } \\
\text { super dust }\end{array}$ & $\begin{array}{l}\text { Fenitrothion } 1 \%+ \\
\text { deltamethrin } 0.13 \%\end{array}$ & 12.5 & $\bullet$ & $\bullet$ & & $\checkmark$ & $\checkmark$ & $\checkmark$ & $\checkmark$ \\
\hline $\begin{array}{l}\text { Actellic gold } \\
\text { dust }\end{array}$ & $\begin{array}{l}\text { Pirimiphos-methyl } 1.6 \% \\
\text { + thiamethoxam } 0.36 \%\end{array}$ & 12.5 & $\bullet$ & & $\bullet$ & $x$ & $\checkmark$ & $x$ & $\checkmark$ \\
\hline Chikwapuro & $\begin{array}{l}\text { Pirimiphos-methyl } 2.5 \% \\
\text { + deltamethrin } 0.1 \%\end{array}$ & 10 & $\bullet$ & $\bullet$ & & $\checkmark$ & $\checkmark$ & $\checkmark$ & $\checkmark$ \\
\hline $\begin{array}{l}\text { Ngwena } \\
\text { yedura }\end{array}$ & $\begin{array}{l}\text { Pirimiphos-methyl } 2.5 \% \\
\text { + deltamethrin } 0.2 \%\end{array}$ & 10 & $\bullet$ & $\bullet$ & & $\checkmark$ & $\checkmark$ & $\checkmark$ & $\checkmark$ \\
\hline Super guard & $\begin{array}{l}\text { Pirimiphos-methyl } 1.6 \% \\
\text { + permethrin } 0.4 \%\end{array}$ & 13.9 & $\bullet$ & $\bullet$ & & $\checkmark$ & $\checkmark$ & $\checkmark$ & $\checkmark$ \\
\hline $\begin{array}{l}\text { Untreated } \\
\text { control }\end{array}$ & N/A & N/A & & & & $\checkmark$ & $\checkmark$ & $\checkmark$ & $\checkmark$ \\
\hline
\end{tabular}

722

723

724

725

726

727

728

729 




Figure 1: Mean insect grain damage $(\% \pm$ SEM) recorded in maize stored under different 


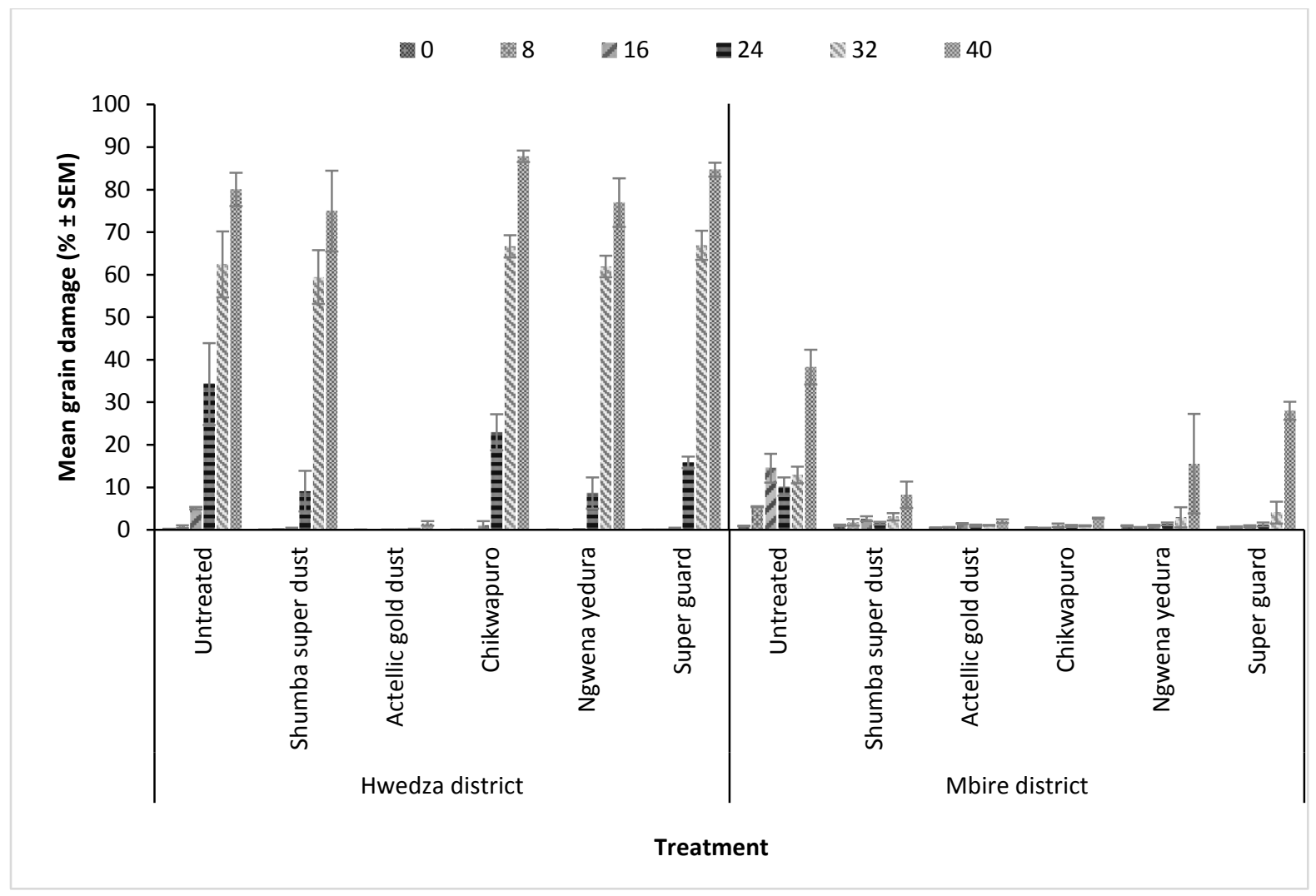

Figure 2: Mean maize insect grain damage $(\% \pm \mathrm{SEM})$ recorded under different treatments in Hwedza and Mbire districts during the $2015 / 16$ storage seasons $(\mathbf{n}=\mathbf{3})$. The legend $0,8,16$ etc. represent the sampling period in weeks 


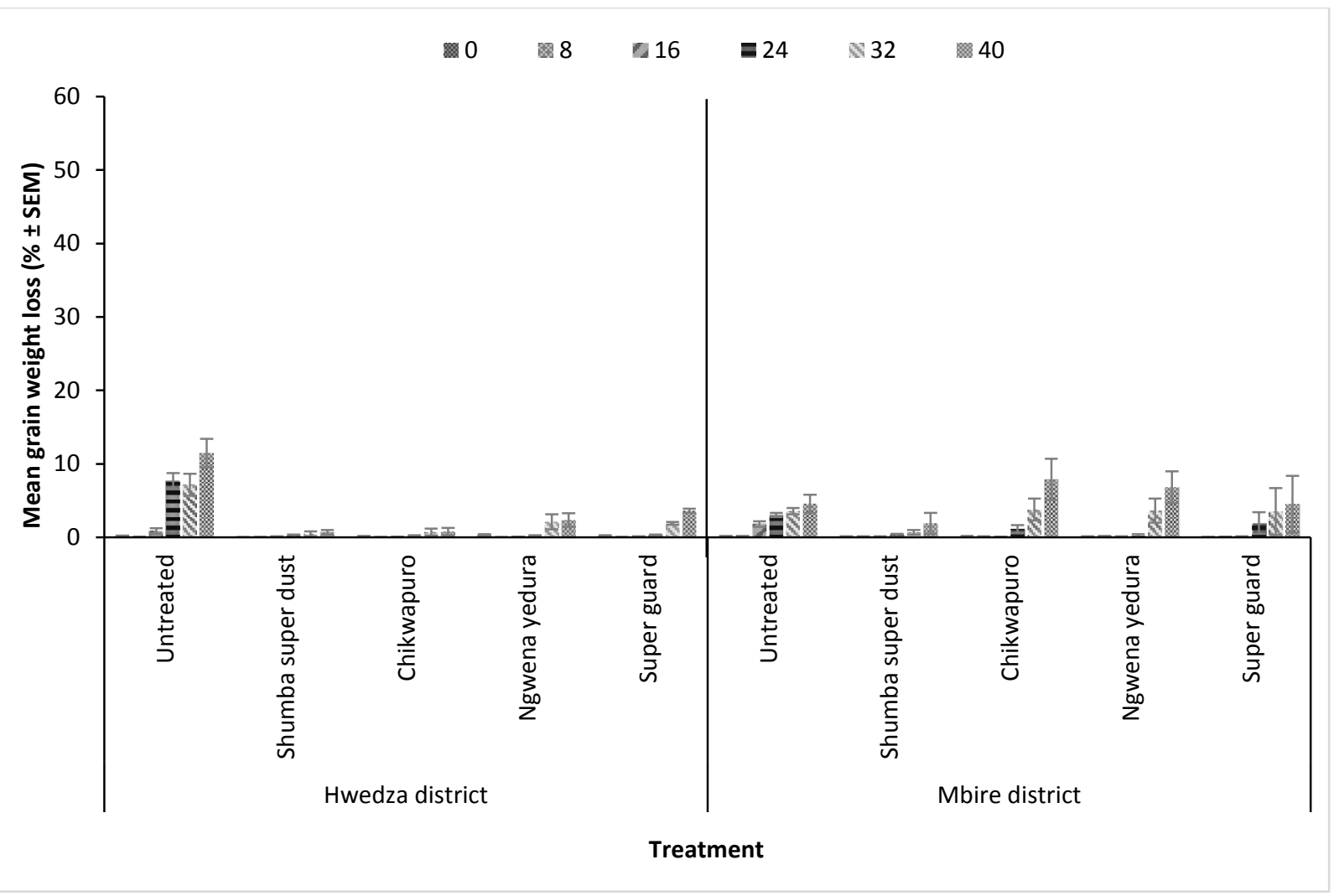

753

Figure 3: Mean maize grain weight loss $(\% \pm \mathrm{SEM})$ recorded under different treatments in

754 Hwedza and Mbire districts during the 2014/15 storage seasons $(\mathbf{n}=\mathbf{3})$. The legend $0,8,16$ etc. represent the sampling period in weeks

756

757

758

759

760

761

762

763 


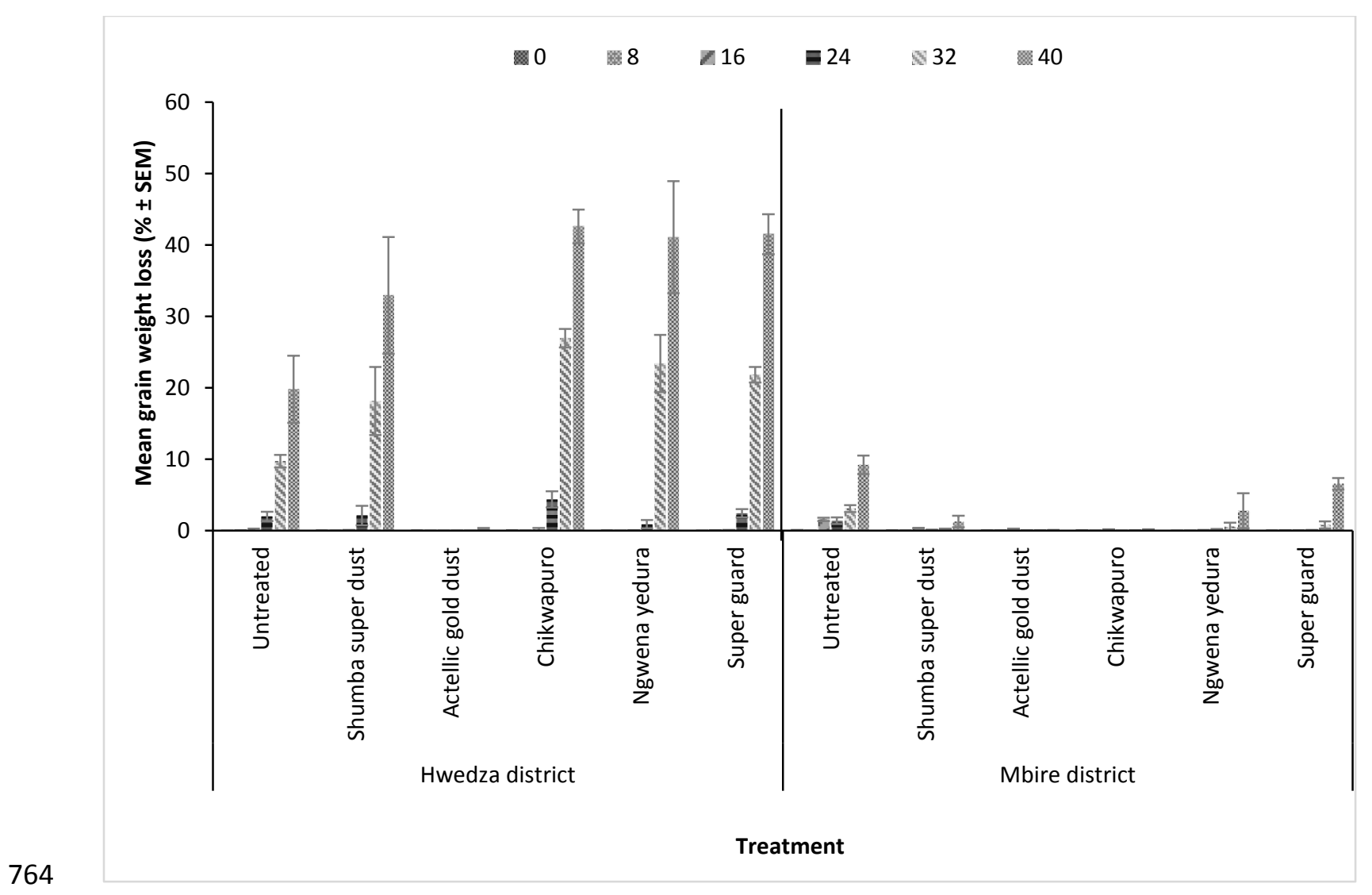

765 Figure 4: Mean maize grain weight loss (\% \pm SEM) recorded under different treatments in 766 Hwedza and Mbire districts during the $2015 / 16$ storage season $(\mathbf{n}=\mathbf{3})$. The legend $0,8,16$ etc. represent the sampling period in weeks 


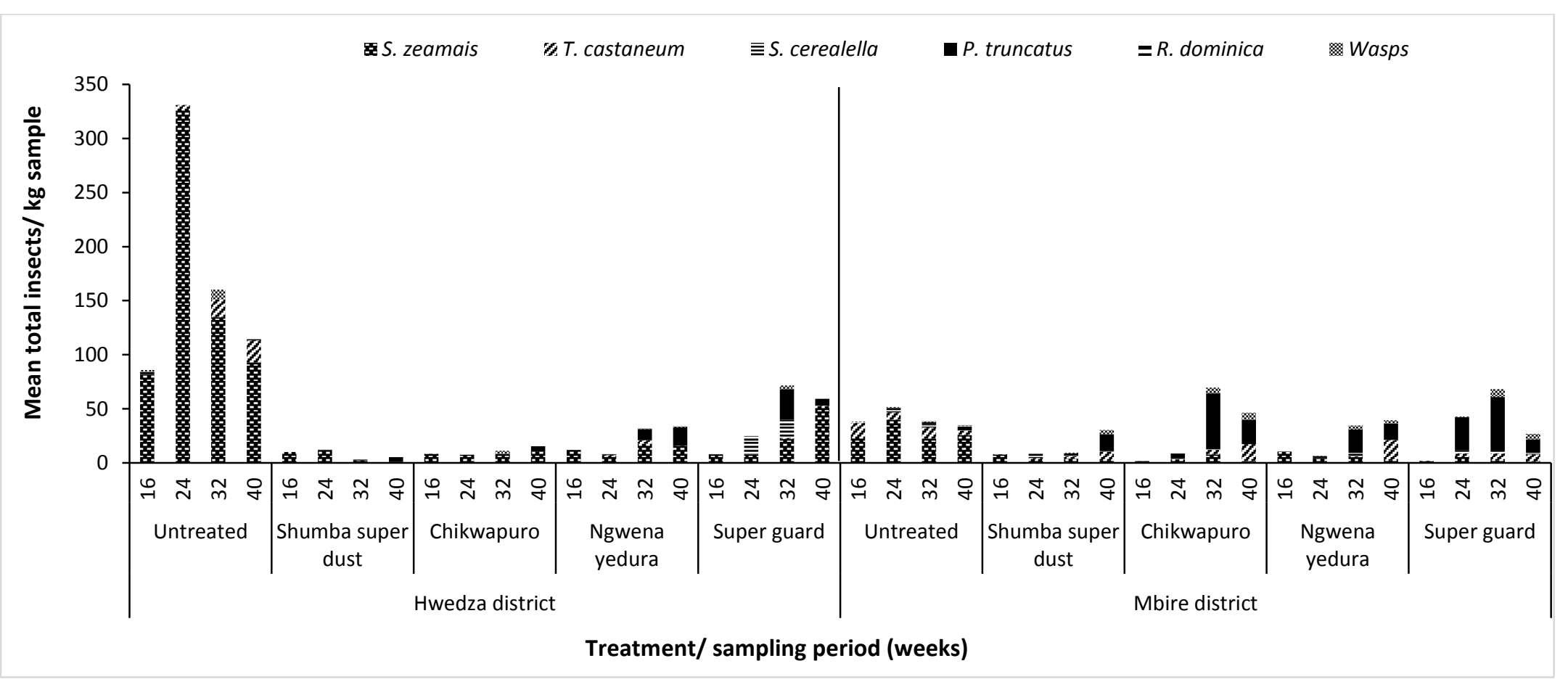
the 2014/15 storage season $(n=3)$. The legend shows insect species recorded 


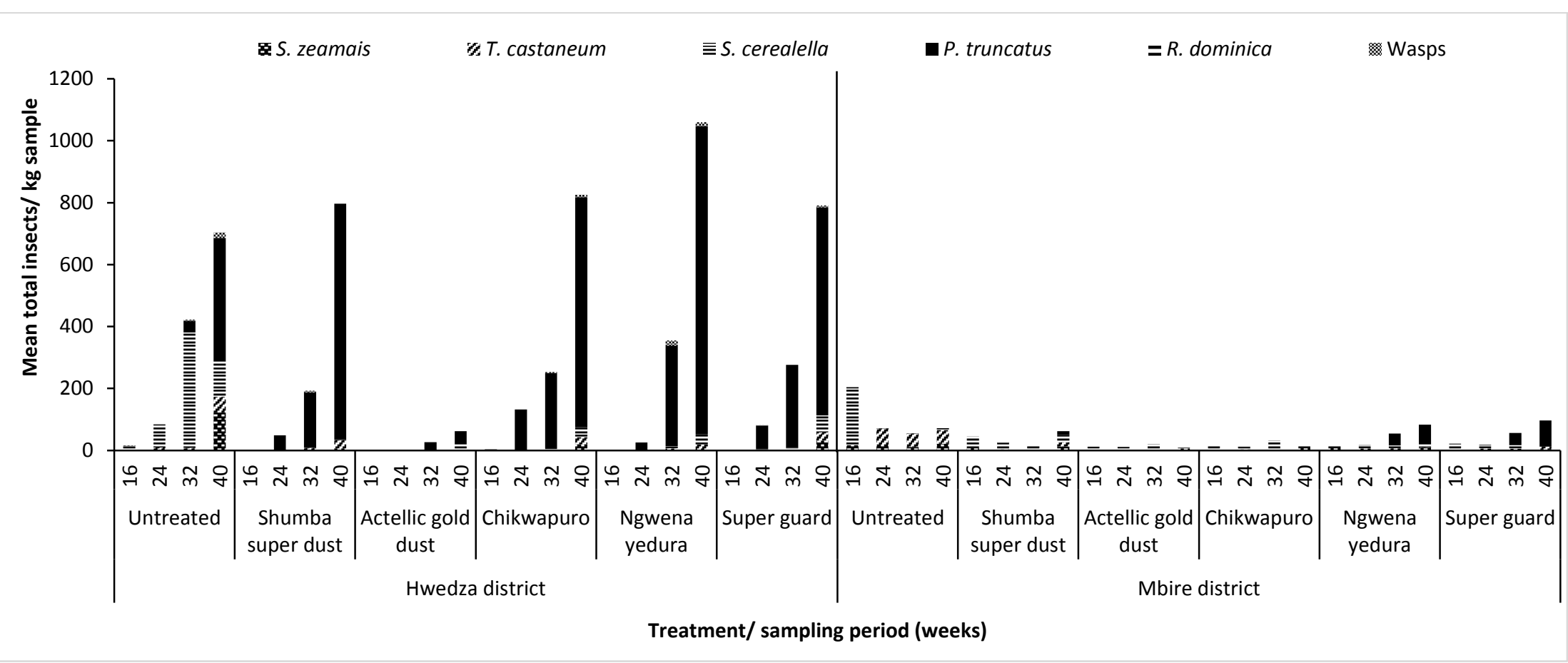

Figure 6: Mean total insects recorded in maize grain stored under different treatments in Hwedza and Mbire districts during the 2015/16 storage season $(n=3)$. The legend shows insect species recorded 


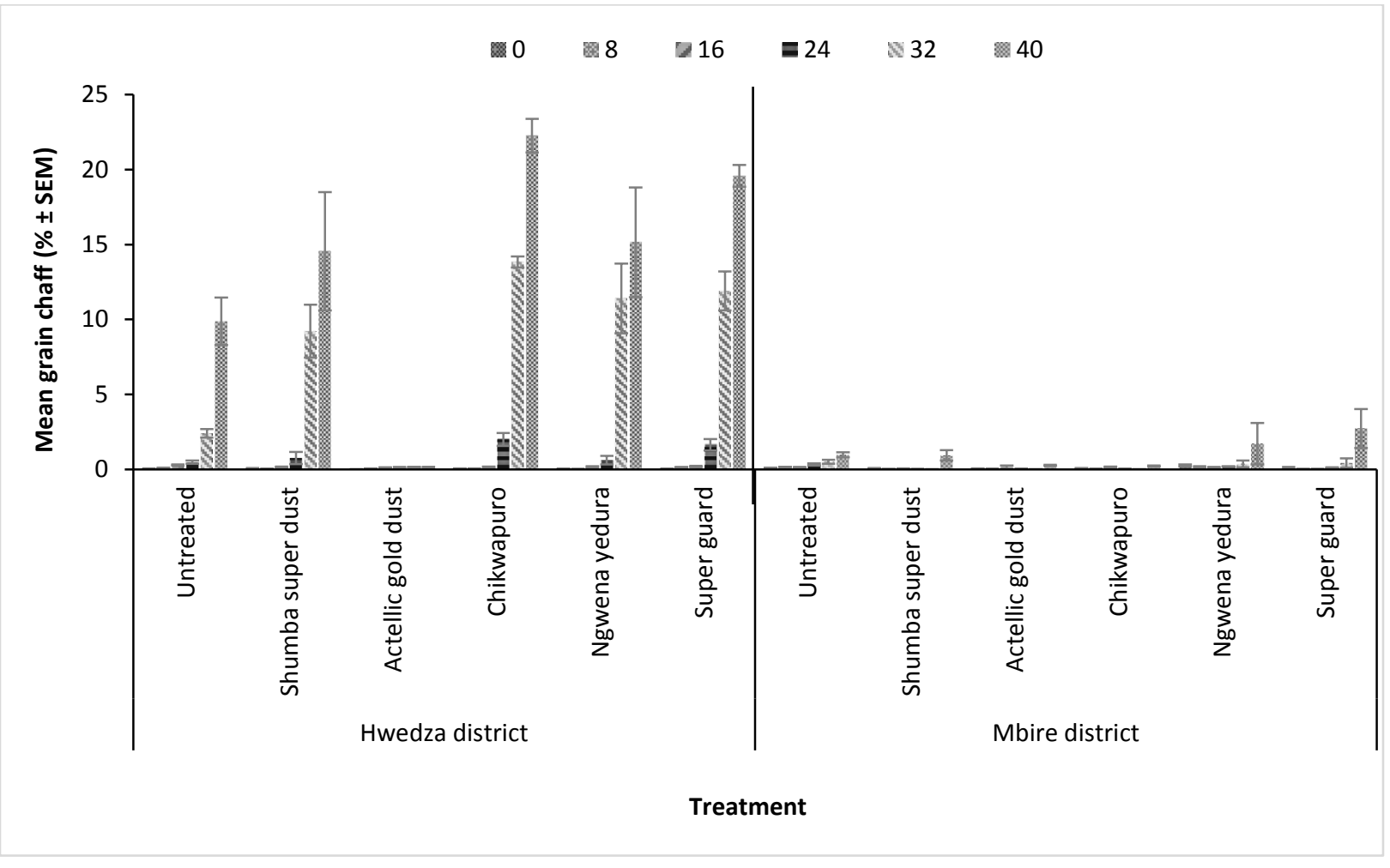

794 Figure 7: Mean chaff $(\% \pm$ SEM) recorded in maize grain stored under different 795 treatments in Hwedza and Mbire during the 2015/16 season $(\mathbf{n}=\mathbf{3})$. The legend $0,8,16$ etc. 796 represent the sampling period in weeks 
803

804

805

806

807

808

809

810

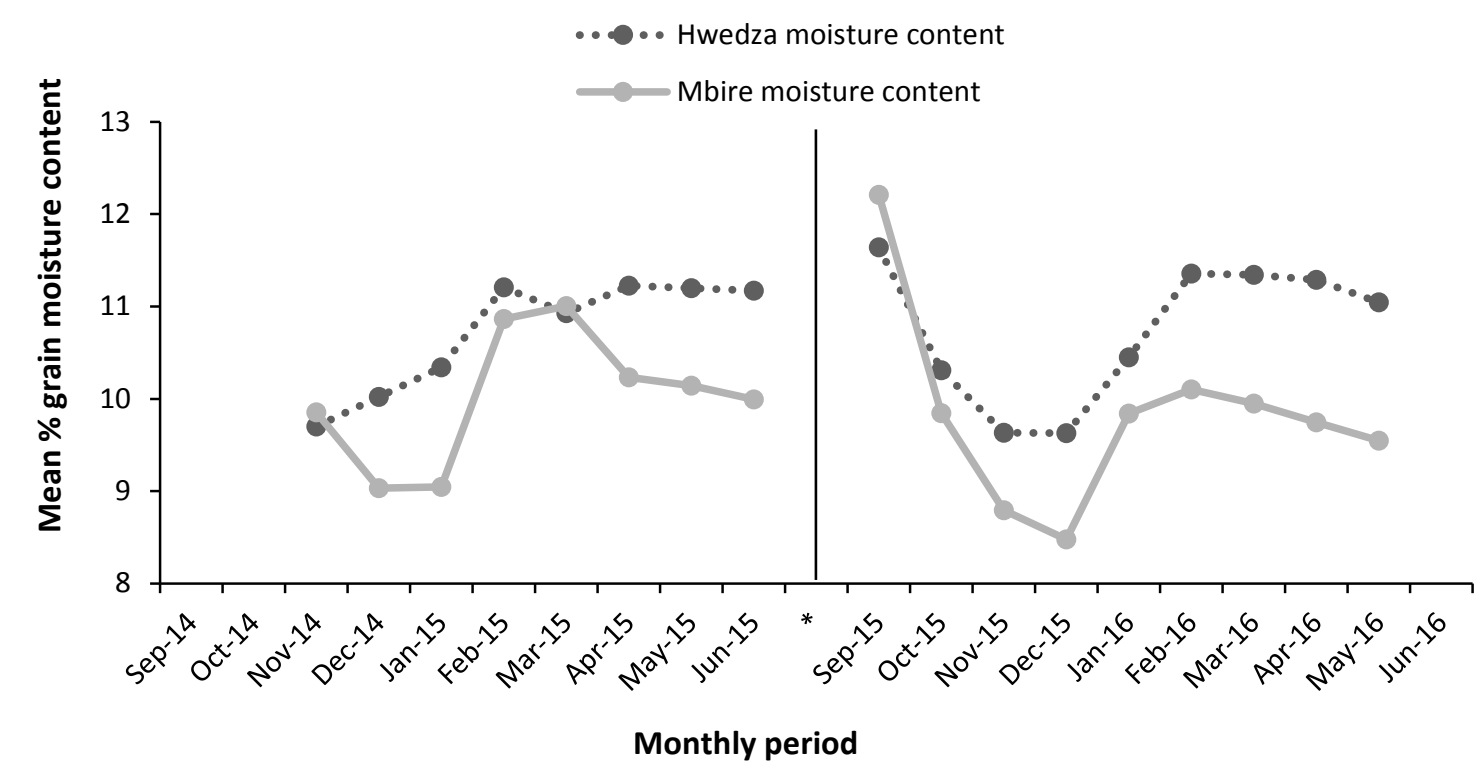

Figure 8: Mean moisture content recorded on maize grain samples in Hwedza and Mbire districts during the $2014 / 15$ and $2015 / 16$ season

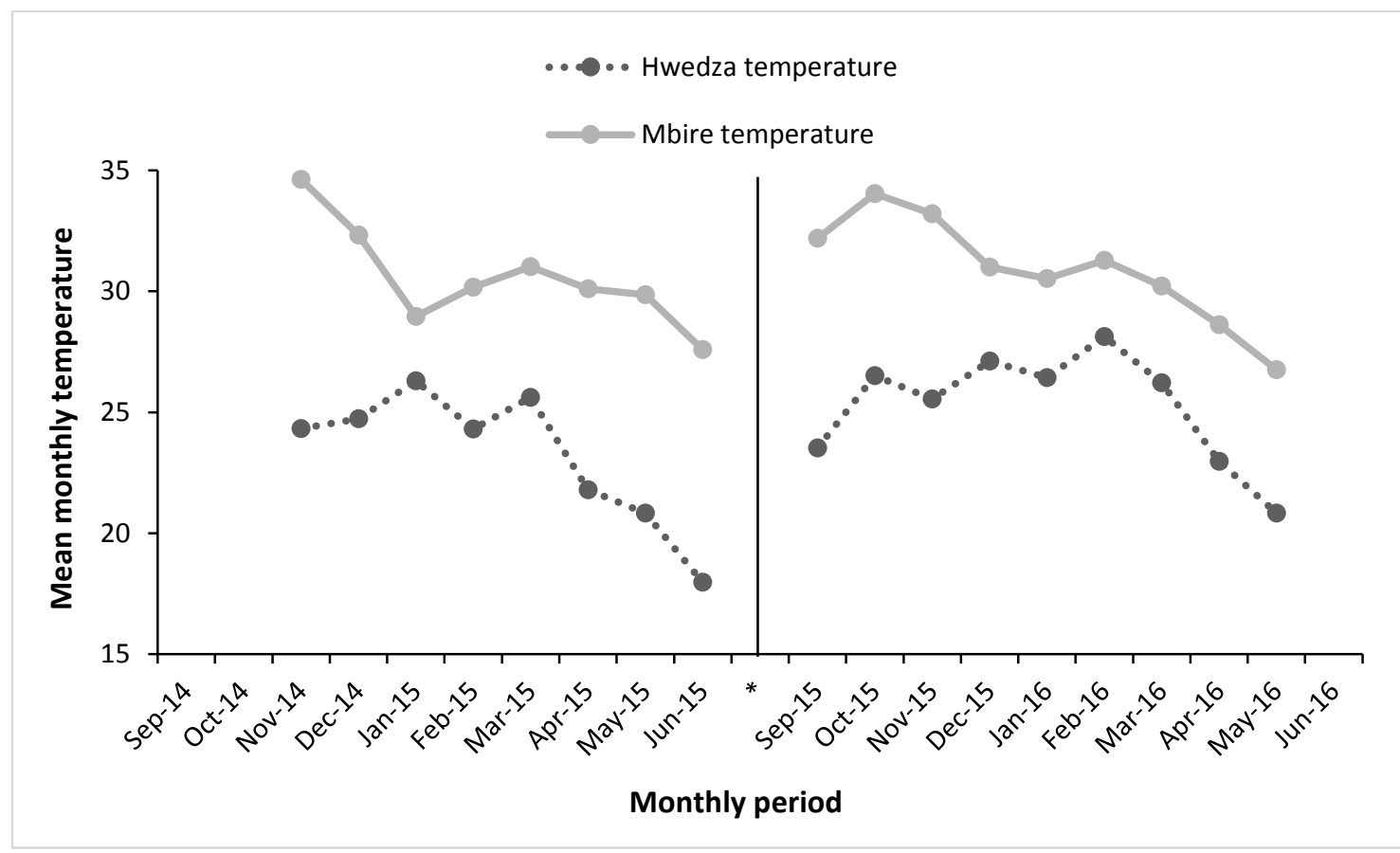

Figure 9: Mean monthly store temperatures recorded in Hwedza and Mbire districts during the 2014/15 and 2015/16 seasons 